\title{
Percutaneous endoscopic gastrostomy - a simple solution to a complex problem
}

\section{Przezskórna gastrostomia endoskopowa - proste rozwiązanie złożonego problemu}

\author{
Przemysław Wolak ${ }^{1,2}$, Renata Skiba ${ }^{3}$, Wojciech Niedziela ${ }^{4}$ \\ ${ }^{1}$ Department of Paediatric Surgery, Urology and Traumatology, Faculty of Medicine and Health Sciences, Jan Kochanowski University, \\ Kielce, Poland \\ Head of the Department: Przemysław Wolak MD, PhD \\ ${ }^{2}$ Department of Anatomy, Institute of Medical Sciences, Faculty of Medicine and Health Sciences, Jan Kochanowski University, Kielce, \\ Poland \\ Head of the Department: Tadeusz Kuder MD, PhD, Prof. JKU \\ ${ }^{3}$ Operating Theater of the Voivodeship Specialist Pediatric Hospital, Kielce, Poland \\ Head of the Theater: Dr. Wojciech Wąsacz \\ ${ }^{4}$ Department of Paediatric Surgery, Urology and Traumatology, Voivodeship Specialist Hospital, Kielce, Poland \\ Head of the Department: Dr. Piotr Stępień
}

Key words: gastrointestinal intubation, child, gastrostomy, protein-energy malnutrition.

Słowa kluczowe: zgłębnikowanie żołądka i jelit, dziecko, gastrostomia, niedożywienie białkowo-energetyczne.

\begin{abstract}
Percutaneous endoscopic gastrostomy (PEG) was performed for the first time in the world on 12 June 1979. At present, the method of using gastrostomy has almost entirely superseded classical methods, which is related with its simplicity, lower costs, lack of need for hospital stay (PEG is often placed in ambulatory conditions) or a shorter period of hospitalisation, as well as a smaller number of complications compared to classical methods. The indications for gastrostomy are possibilities of feeding directly into the gastrointestinal tract, avoiding the oral cavity, throat, and oesophagus (for various reasons), or decompression of the gastrointestinal tract in the case of its obstruction as a palliative procedure. Gastrostomy may be performed by a classical open technique or by laparoscopic or endoscopic methods. Percutaneous endoscopic gastrostomy is the most common form of gastrostomy.
\end{abstract}

\section{Streszczenie}

Przezskórna gastrostomia endoskopowa (PEG) została wykonana po raz pierwszy na świecie 12 czerwca 1979 r. Obecnie endoskopowe zakładanie gastrostomii prawie całkowicie wyparło metody klasyczne ze względu na prostotę, niższe koszty, brak konieczności pobytu w szpitalu (często PEG zakłada się ambulatoryjnie) lub krótszy okres hospitalizacji, a także mniejszą liczbę powikłań niż w przypadku metod klasycznych. Wskazaniami do gastrostomii są żywienie poprzez przewód pokarmowy z ominięciem jamy ustnej, gardła i przełyku (z różnych przyczyn) lub odbarczenie przewodu pokarmowego przy niedrożności przewodu pokarmowego jako postępowanie paliatywne. Gastrostomia może być założona metodą klasyczną, laparoskopową lub endoskopową. Przezskórna gastrostomia endoskopowa jest najbardziej powszechną formą gastrostomii.

Percutaneous endoscopic gastrostomy (PEG) was performed for the first time in the world in operating room conditions on a 4.5-month-old child in Cleveland University Hospital on 12 June 1979. The procedure was performed by paediatric surgeon $\mathrm{Mi}$ chael Gauderer and endoscopist Jeffrey Ponsky [1, 2]. Although the procedure was met with favour by oncologists and neurologists, for many years since, paediatric surgeons have continued to regard it with great scepticism [3]. At present, the method of using gastrostomy has almost entirely superseded classical methods, which is related with its simplicity, lower costs, lack of need for hospital stay (PEG is often placed in ambulatory conditions) or a shorter period of hospitalisation, as well as a smaller number of complications compared to classical methods [4]. The indications for gastrostomy are possibilities of feeding directly into the gastrointestinal tract, avoiding the oral cavity, throat, and oesophagus (for various reasons), or decompression of the gastrointestinal tract in the case of its obstruction as a palliative procedure. Gastrostomy may be performed by a classical open 
technique or by laparoscopic or endoscopic methods. Percutaneous endoscopic gastrostomy is the most common form of gastrostomy, and today in the USA approximately 220,000 endoscopic gastrostomy procedures are performed annually. The PEG may be inserted even in infants with body weight of over 3 $3.5 \mathrm{~kg}$ [5]. Recent reports and a change in the method of placing the PEG proposed by Seifarth, described as an endoscopic gastrostomy button with a double-lasso [6], patterned on the laparoscopic technique for inguinal hernia repair by Patkowski et al. [7, 8], allows the placement of the PEG in children with weight below $3 \mathrm{~kg}$ [6]. It is the method of enteral feeding applied in the group of patients whose clinical status makes oral food supply impossible or considerably limited. The PEG enables the discontinuation of feeding through a nasogastric or orogastric tube, which are short-term use methods (up to maximum 3-4 weeks) of feeding patients. The PEG enables avoidance of complications related with a long-term maintenance of a nasogastric tube, such as:

- Erosion, pressure sores of the nasal alas (caused by the direct adhesion of the tube, which must be additionally fixed and not fall out, most often using a sticking plaster). Insertion of the probe for each meal applied, in some cases is also associated with the necessity to perform an invasive procedure each time.

- Ulcers, inflammation, and narrowing of the oesophagus (causes as mentioned above).

- Impairment of ventilation (one of the nasal apertures is blocked, while the youngest patients breathe through the nose; replacement of the respiratory route by oropharyngeal instead of nasopharyngeal increases the frequency of infection of the airways the inhaled air is insufficiently purified, heated, and moisturised).

- Sinusitis and, middle ear infection.

Percutaneous endoscopic gastrostomy is applied to prevent malnutrition in patients in whom oral feeding is not possible or insufficient. It should be remembered that malnutrition increases mortality and morbidity in the human population, prolongs the period of hospitalisation due to delayed recovery, and consequently increases the costs of hospitalisation and treatment. Thus, for the patients themselves, it is one of the major factors exerting an effect on the deterioration of the quality of life. By enteral feeding, i.e. through the gastrointestinal tract, the correct physiological and natural route of food supply is maintained (obviously omitting the upper section of the gastrointestinal tract) but while still maintaining the functions of the stomach and intestines. In the case of abandoning this route, there develop changes in the intestines (a decrease in the enzymatic activity of the brush border, occurrence of villous atrophy, an increase in the permeability of the mucosa for micro- organisms and pathogens, and development of disorders in the secretion of hormones responsible for intestinal metabolism and motility).

Algorithm procedure - selection of an appropriate tube for enteral feeding was established by the European Society for Clinical Nutrition and Metabolism (ESPEN) in 2005 [9]. A nasogastric or nasointestinal tube is inserted in a patient in the case of the lack of possibilities of oral feeding or an insufficient supply of food by mouth, with a short-term use (up to 2-3 weeks of application) or at the beginning of nutritional treatment when the period of the lack of possibilities of oral feeding is difficult to determine. In the case when there is no risk of aspiration of gastric content, the nasogastric tube is selected, whereas with the presence of the risk of aspiration of gastric content, a gastrojejunal tube should be used. If the duration of oral feeding will be longer than 3 weeks, in patients who previously had not undergone surgical procedures (lack of previous abdominal surgeries - laparotomy), and with the lack of aspiration of gastric content, PEG is recommended. In the case of occurrence of the risk of aspiration of gastric content in patients who had not been operated on due to gastrointestinal causes, the PEJ tube (percutaneous endoscopic jejunostomy) or a JET-PEG (PEG with a jejunal catheter) are preferred. In patients with gastro-oesophageal reflux disease and in patients with neurological disorders of the type of cerebral palsy, an additional performance of anti-reflux oesophageal bypass surgery by the classic laparoscopic method should be considered, as well as an additional performance of pyloromyotomy (pyloroplasty). Then, the risk of aspiration of gastric content with the presence of the PEG is minimised. In the case of long-term lack of the possibility to use an oral route in patients who had formerly undergone laparotomy procedures, the NCJ (needle catheter jejunostomy) is recommended. According to the recommendations by the ESPAN - in feeding using PEG or PEJ, food is supplied into the stomach or peripherally to the duodeno-jejunal flexure, because administration of food into the duodenum does not have any medical justification. Apart from this, when endoscopic insertion of the tube is technically impossible (e.g. oesophageal stenosis), laparoscopic gastrostomy should be considered. Four weeks after placement of the PEG, when the stoma channel is healed, i.e. mature and fixed, an exchange of PEG into the mushroom-type gastrostomy may be taken into account. This is especially convenient for active individuals, it is easy to 'disguise', and it does not interfere with occupational activity or children attending school. The national equivalent of the ESPEN in Poland is the Polish Society for Parenteral, Enteral Nutrition, and Metabolism (POLSPEN) - the largest and the oldest Polish society dealing with the scope of problems concerning nutrition therapy, clinical nutrition, and metabolism. 
In children who, for various reasons, cannot be fed by mouth, feeding by the gastrointestinal route should be implemented with the omission of the mouth, throat, and oesophagus, i.e. parenteral and enteral. It should be taken into consideration in the case of the possibility of obtaining safe access to the gastrointestinal tract and maintaining its (even limited) function in the following clinical situations [10, 11]:

- when oral supply is insufficient to cover the demand by the oral route;

- when in a child under the age of 2 years there occurs an impairment of growth or body weight gain which lasts longer than 1 month;

- when in a child over the age of 2 years there occurs an impairment of growth or body weight gain which lasts longer than 3 months;

- when a deviation is observed in body weight in relation to age or growth of over two centile channel widths;

- when the measured skinfold thickness is below the fifth percentile.

General indications for PEG in children [10, 11]:

1) Diseases of the nervous system leading to disorders in suckling, chewing, and swallowing, which render impossible the physiological way of nutrition (primary neurological causes). The following diseases should be mentioned: cerebral palsy, hypoxic-ischaemic encephalopathy, cerebrocranial injuries with a long-lasting loss of consciousness, congenital defects of the central nervous system, bleeding into the central nervous system, brain cancer, congenital cytomegaly, toxoplasmosis, and others. In the case of cerebral stroke and swallowing disorders (dysphagia of neurologic aetiology) - swallowing disorders make oral food supply impossible, while after the placement of PEG it is possible to simultaneously carry out rehabilitation of the swallowing function (the presence of a tube excludes rehabilitation). The presence of PEG in the stomach does not exclude the possibility of maintaining the swallowing reflex and attempts of oral administration of food. The administration of diet through PEG is applied to prevent malnutrition when oral feeding is insufficient and ineffective. In the case of amyotrophic lateral sclerosis (ALS), PEG should be inserted in an early period of the disease because the occurrence of pulmonary function disorders of a restrictive type considerably limits the chances for a successful procedure and its use. In dementia syndromes, when the nutritional goals are attained, there often occurs an improvement of the functional status, prevention of hunger, an improvement of comfort and prevention of the development of sores.

2) Metabolic diseases which secondarily cause neurologic disorders: mucopolysaccharidosis type III (MPS III), hyperammonaemia, ceroid lipofuscinosis, Niemann-Pick disease, adrenoleukodystrophy, hyperinsulinaemic hypoglycaemia, glycogen storage disease type 1a, mitochondrial cytopathy.

3) Gastrointestinal tract diseases: short bowel syndrome, oesophageal and laryngeal stenosis after chemical burns, intestinal pseudo-obstruction syndrome - PEG is applied to decompress the stomach.

4) Mucoviscidosis (feeding at night by PEG results in an improvement of nutritional status, stabilises lung function).

5) Anorexia of central origin.

6) Cancer of the nasopharynx, oesophagus, face, mouth.

7) Crohn's disease.

8) In children with a large growth delay and in malnourished patients.

Contraindications to PEG placement $[9,10]$ : blood coagulation disorders (INR $>1.5$, Quick index $<50 \%$, PTT $>50 \mathrm{~s}$, platelet count $\left.<50,000 / \mathrm{mm}^{3}\right)$; interposition of organs, e.g. the liver (a relative contraindication); ascites to a considerable degree (a relative contraindication); peritonitis; severe psychosis; bone deformities with translocation of internal organs (cerebral palsy with extensive contractures, severe kyphoscoliosis); considerable shortening of the expected survival rate; advanced peritoneal metastasis.

In patients with severe neurological disorders with the risk of reflux and aspiration of gastric content, a simultaneous diaphragm fundoplication, i.e. anti-reflux oesophageal surgery, should be considered.

Contraindications for the placement of PEG are not the following: consumption of low doses of non-steroid anti-inflammatory drugs; moderate ascites; presence of ventriculoperitoneal shunt; performance of peritoneal dialyses; pregnancy; peptic ulcer - after healing.

A basis for the placement of PEG is the possibility of luminescence of the anterior stomach wall by light from a gastroscope placed in the stomach. This prevents the possibility of piercing or damaging the adjacent organs, such as the transverse colon, liver, enlarged spleen, and others remaining in the stomach - abdominal wall conflict.

Preparation of patient for placement of PEG:

1) The surgical procedure, although minimally invasive, causes a break in the continuity of tissues; therefore, informed consent of the patient or his/ her legal caregiver is needed. In a child aged over 16 years, the child's consent is also necessary. In the case of patients who cannot express their will due to mental status or unconsciousness, consent for the procedure is made by the legal caregiver, who expresses it in writing.

2) Analysis of complete surgical records is required, i.e. establishing indications to PEG, determination of the patient's weight with specification of deficiencies, performance of basic tests, whole blood count with specification of platelet count, and, if 
needed, determination of other parameters of the coagulation system, determination of blood group, antigens HCV, HBs, HIV; an abdominal ultrasound may be performed as an additional useful examination (allows determination of the size of organs which may enter into 'collision' with the site of probable placement of PEG, e.g. liver, spleen) or plain abdominal radiography (deformations and bone deformities)

3) In adults - the procedure is performed under sedation, in children under general anaesthesia, only in adolescents with the full cooperation of the patient it is possible to place PEG under sedation and local anaesthesia. Expanded indications to procedures under local anaesthesia in children should always be remembered.

4) The patient should fast (neither eating nor drinking for $6 \mathrm{~h}$ prior to surgery) to avoid the possibility of aspiration of gastric content; in patients with neurological disorders this period may even be longer. Before the procedure, an insertion of the tube into the stomach may be considered, as well as sucking out gastric content using an endoscope.

5) It is not necessary to discontinue administration of drugs of the type of $\mathrm{H}_{2}$ blockers proton pump inhibitors.

6) Antibiotic prophylaxis is required - cefazolin IV the discussions continue; however, the results of meta-analysis confirmed clinical benefits from administration of a single dose of an antibiotic.

Methods of placement of PEG [9-11]:

- The pull-string PEG technique is the simplest, the safest, and most often applied. It requires the presence of at least two persons, most often a surgeon and an endoscopist. After insertion of the gastroscope into the stomach, by filling it with air, there occurs adhesion of the stomach to the anterior abdominal wall. At the site of the best luminescence (backlighting), the stomach wall is punctured under endoscopic control. A loop is inserted through the needle which is captured by an endoscopist and pulled outside through the stomach, oesophagus, throat, and the oral cavity. Into this loop, the PEG is attached and pulled through the oral cavity, throat, oesophagus, and the stomach, pulling out the abdominal wall, leaving the end of the PEG in the stomach, the socalled 'mushroom', in the stomach. The method is difficult to apply in the smallest patients with the weight under $3 \mathrm{~kg}$, and in patients with tracheostomy or other anatomic obstacles in the upper section of the gastrointestinal tract. During pulling, the gastrostomy 'mushroom' may become stuck in the narrowest place. Apart from this, there are reports concerning damage to the oesophagus and mediastinitis following a forceful placement of PEG. Therefore, in the context of the above-mentioned difficulties, the Seifarth method may prove to be an effective solution to this problem [6].
- The push technique (Seldinger) is similar to the previous one. The gastrostomy tube is placed in the stomach by passing it over a guidewire by means of special pushers.

- Direct puncture (poorly popular) - introducer technique - similar to that used in the repair of percutaneous fistula of the urinary bladder. A modification of this method is the Endoscopic Gastrostomy Button with Double-Lasso U-Stitch technique [6].

The main recommendationis that a tube for PEG must have a large lumen should be inserted (prevention of clogging with the administred food).

- Supply of liquids for gastrostomy approximately $1-2 \mathrm{~h}$ after placement (5\% glucose, $0.9 \%$ saline, boiled water - from several to more than a dozen $\mathrm{ml}$ according to age).

- Supply of industrial diet approximately $24 \mathrm{~h}$ after in $1: 1$ dilution with $5 \%$ glucose or $0.9 \%$ saline.

- Placing the patient in a left lateral position should be avoided (possibility of leakage through the fistula).

- Checking of retention by aspiration of gastric content approximately $1 \mathrm{~h}$ after the application of food - especially while determining dietary doses.

- Washing the drainage tube with boiled water (washing out gastric content) and placing the clamp after completing food supply. This prevents gastrointestinal infections due to the proliferation of bacteria on the medium, which is food retained in the PEG. The clamp makes it impossible for gastric contents to flow out of the PEG.

- The temperature of the meal should not exceed $40^{\circ} \mathrm{C}$, optimum $35-37^{\circ} \mathrm{C}$.

- Placing a lying patient in a semi-sitting position.

- Offering the cooperative patient chewing gum, sucking a sweet with a strong aroma 15-30 min before the meal, irritation of the sense of smell by the aroma of meals - stimulation of secretion of the digestive enzymes.

- Provision of oral and nasal cavity hygiene.

- It should be remembered that foods supplied directly to the stomach do not provide any possibility to differentiate their taste and therefore may have a bad taste when supplied orally.

The most frequent nursing problems in patients with PEG are as follows:

1) Leakage of gastric content around the PEG - may be caused by an excessively wide gastrostomy channel with respect to the PEG tube - so-called 'wearing out' of the gastrostomy channel. Specimen for culture should be collected from the channel, and food supply to the PEG discontinued for more than $10 \mathrm{~h}$, taking into consideration only the administration of small amounts of liquids. In the case of persistent leakage, an exchange of the PEG for a larger size tube may be taken into account.

2) Sore around the gastrostomy - adhesion of the PEG to the stomach wall should be controlled, placing gauge pads under the PEG should be avoided be- 
cause this leads to the widening of the gastrostomy opening and leakage of content around the PEG. A vicious circle occurs, and an increasingly large gastrostomy opening causes greater leakage, which results in enlargement of the opening through which PEG passes, and an increasingly large leakage of the gastric content. Acidic (low) pH causes chemical burns to the skin around PEG.

3) Hypertrophy of mucosa around gastrostomy - lapis impregnation - application of $20-40 \%$ of silver nitrate water solution (argentum nitricum) or excision of the mucosa.

4) Mechanical damage to the PEG - cracking of the balloon, breaking the continuity of the drainage tube - the kit should be exchanged.

5) Clogging of gastrostomy - difficult to be mechanically unblocked - results from administration of excessively thickened liquids or lack of washing out the PEG after meals - usually an exchange of the kit is necessary.

6) Constipation or diarrhoea - use of inadequate diets or excessive speed of administration of industrial diets.

7) Aspiration of gastric content to the bronchial tree - improper position of the patient during feeding, presence of gastroesophageal reflux disease, and excessive volumes of food.

Management in accordance with the guidelines increases the accuracy of selection of patients (medically justified PEG) and is translated into better outcomes of treatment. Enteral feeding through a PEG tube is a simple and very effective technique for feeding patients. The PEG is characterised by a low incidence of complications. It helps to maintain an appropriate state of nutrition in patients who are incapable of oral feeding, and considerably improves their comfort of life.

\section{Conflict of interest}

The authors declare no conflict of interest.

\section{References}

1. Gauderer M, Ponsky J, Izant RJ. Gastrostomy without laparotomy: a percutaneous endoscopic technique. J Pediatr Surg 1980; 15: 872-5.

2. Gauderer M, Ponsky J, Izant RJ. Gastrostomy without laparotomy: a percutaneous endoscopic technique. $\mathrm{Nu}-$ trition 1998; 14: 736-8.

3. Gaudner M. Twenty years of percutaneous gastrostomy: origin and evolution of a concept and its expanded applications. Gastrintest Endosc 1999; 50: 879-83.

4. Bobrzyński A, Budzyński A, Bolt L, Wysocki A. Małoinwazyjne zabiegi paliatywne $\mathrm{w}$ leczeniu nieoperacyjnych nowotworów przewodu pokarmowego. Videochirurgia 1999; 4: 49.

5. Wilson L, Olivia-Hemker M. Percutaneous endoscopic gastrostomy in small medically complex infants. Endoscopy 2001; 33: 433-6.
6. Seifarth FG, Dong ML, Guerron AD, Lozada JS, Magnuson DK. Endoscopic gastrostomy button with doublelasso U-stitch in children. JSLS 2015; 19: e2015.00002.

7. Patkowski D, Czernik J, Chrzan R, Jaworski W, Apoznański W. Percutaneous internal ring suturing: a simple minimally invasive technique for inguinal hernia repair in children. J Laparoendosc Adv Surg Tech A 2006; 16: 513-7.

8. Wolak P, Patkowski D. Laparoscopic inguinal hernia repair in children using the percutaneous internal ring suturing technique-own experience. Videosurgery Miniinv 2014; 9: 53-8.

9. Löser C, Aschl G, Hébuterne X, Mathus-Vliegen EM, Muscaritoli M, Niv Y, Rollins H, Singer P, Skelly RH. ESPEN guidelines on artificial enteral nutrition percutaneous endoscopic gastrostomy (PEG). Clin Nutr 2005; 24: 848-61.

10. Axelrood D, Kazmerski K, Iyer K. Pediatric enteral nutrition. JPEN J Parenter Enteral Nutr 2006; 30 (Suppl. 1): S21-6.

11. Łyszkowska M, Bogucki K, Celińska-Cedro D, Cedro A, Teisseyre M, Woynarowski M, Książyk J, Kierkuś J, Popińska K, Socha J. Zastosowanie przezskórnej endoskopowej gastrostomii (PEG) w pediatrii. Pediatr Współcz Gastroenterol Hepatol Żyw Dziecka 2002; 4: 299-301.

\section{Address for correspondence:}

\section{Przemysław Wolak}

Institute of Nursing and Obstetrics

Department of Health Sciences

Faculty of Medicine and Health Science

Jan Kochanowski University

al. IX Wieków Kielc 19, 25-317 Kielce, Poland

Phone: +48501525 549

E-mail: przemyslaw.wolak@ujk.edu.pl 